\title{
Photovoltaic Properties of Doped Zinc Sulfide/n-Si Heterojunction Thin Films
}

\author{
Mahdi H. Suhail ${ }^{1}$, Omed Gh. Abdullah ${ }^{2,3, *}$, Raoof A. Ahmed ${ }^{4}$, Shujahadeen B. Aziz ${ }^{2}$ \\ ${ }^{1}$ Department of Physics, College of Science, University of Baghdad, Baghdad, Iraq. \\ ${ }^{2}$ Department of Physics, College of Science, University of Sulaimani, Sulaymaniyah, Iraq. \\ ${ }^{3}$ Komar Research Center, Komar University of Science and Technology, Sulaymaniyah, Iraq \\ ${ }^{4}$ Directorate of Education Salahuddin, Education Department of Tuz, Salahuddin, Iraq. \\ *E-mail: omed.abdullah@univsul.edu.iq
}

doi: $10.20964 / 2018.02 .50$

Received: 16 October 2017 / Accepted: 13 December 2017 / Published: 28 December 2017

In this work, the current-voltage (I-V) characteristic curve of heterojunction solar cells based on pure $\mathrm{ZnS}$ and doped $\mathrm{ZnS}$ solid films have been studied. The films of pure and doped $\mathrm{ZnS}$ samples were deposited onto silicon substrates using the low-cost spray pyrolysis technique. Different weight ratios of $\mathrm{Pb}, \mathrm{Mn}$ and $\mathrm{Cu}$ species were used for doping the $\mathrm{ZnS}$ films. The four-point probe electrical resistance technique has been used to measure thin films resistance, to evaluate the electrochemical performance of the hybrid solar cells. The photovoltaic properties and the forward I-V characteristics of the doped films were studied at room temperature. The solar cell efficiency, ideality factor, and other parameters were estimated. The results revealed that the efficiency, as well as the ideality factor, depends on the dopant concentration in the hybrid cells. The maximum power efficiency achieved was $3.5 \%$ at $\mathrm{x}=4 \%$ for $\mathrm{Zn}_{1-\mathrm{x}} \mathrm{S}: \mathrm{Pb}_{\mathrm{x}}, 1.84 \%$ at $\mathrm{x}=10 \%$ for $\mathrm{Zn}_{\mathrm{x}-1} \mathrm{~S}: \mathrm{Mn}_{\mathrm{x}}$, and $3.06 \%$ at $\mathrm{x}=8 \%$ for $\mathrm{Zn}_{\mathrm{x}-1} \mathrm{~S}: \mathrm{Cu}_{\mathrm{x}}$ structure.

Keywords: Photovoltaic properties; ZnS/n-Si; heterojunction solar cells; spray pyrolysis technique; efficiency; ideality factor.

\section{FULL TEXT}

(C) 2018 The Authors. Published by ESG (www.electrochemsci.org). This article is an open access article distributed under the terms and conditions of the Creative Commons Attribution license (http://creativecommons.org/licenses/by/4.0/). 